\title{
ANALISIS PENGARUH PEMBANGUNAN INFRASTRUKTUR TRANSPORTASI TERHADAP PRODUK DOMESTIK REGIONAL BRUTO KOTA AMBON
}

\author{
Aram Palilu \\ Universitas Victory Sorong, Papua Barat. \\ arampalilu1015@gmail.com
}

\begin{abstract}
Analysis of Effects of Transportation Infrastructure Development Toward Gross Regional Domestic Product of Ambon City. The availability of inadequate and quality transportation infrastructure positively affects a region's gross domestic product (GRDP) to below. This study aims to analyze the influence of transportation infrastructure development, namely road infrastructure, seaport infrastructure and airport infrastructure on Ambon City GRDP. The research method used in this study is a quantitative method. The results of multiple regression calculations show that 1) the road infrastructure has a significant number of 0.010 below 0.05; meaning that the independent variable has a substantial effect on GRDP. 2) seaport infrastructure, the considerable amount is 0.309 above 0.05; saying that these variables have not significantly affected gross regional domestic products. 3) Airport infrastructure, a significant number of 0.093 above 0.05; it means that the variable has not changed the GRDP. While the contribution of the research is a reference in development policies, especially the development of transportation infrastructure to increase the GRDP of Ambon City.
\end{abstract}

Keywords: Roads Infrastructure, Seaport Infrastructure, Airport Infrastructure, and Gross Regional Domestic Product.

Abstrak: Analisis Pengaruh Pembangunan Infrastruktur Transportasi Terhadap Produk Domestik Regional Bruto Kota Ambon. Ketersedian infrastruktur transportasi yang tidak memadai dan berkualitas, tentu mempengaruhi produk domestik regional bruto (PDRB) suatu wilayah menjadi rendah. Penelitian ini bertujuan untuk menganalisis pengaruh pembangunan infrastruktur transportasi, yakni infrastruktur jalan, infrastruktur pelabuhan laut dan infrastruktur bandar udara terhadap PDRB Kota Ambon. Adapun metode penelitian yang digunakan dalam penelitian ini adalah metode kuantitatif. Hasil perhitungan regresi berganda, menunjukkan bahwa 1) infrastruktur jalan angka signifikannya 0,010 dibawah 0,05 ; artinya variabel bebas tersebut berpengaruh secara signifikan terhadap PDRB. 2) infrastruktur pelabuhan laut, angka signifikannya 0,309 diatas 0,05; artinya variabel tersebut belum berpengaruh secara signifikan terhadap produk domestik regional bruto. 3) Infrastruktur bandar udara, angka signifikannya 0,093 diatas 0,05; artinya variabel tersebut belum berpengaruh terhadap PDRB. Sedangkan kontribusi penelitian tersebut merupakan referensi dalam kebijakan pembangunan, khususnya pembangunan infrastruktur transportasi dalam upaya meningkatkan PDRB Kota Ambon.

Kata Kunci: Transportasi Jalan, Transportasi Pelabuhan Laut, transportasi Bandar Udara, dan Produk Domestik Regional Bruto. 


\section{PENDAHULUAN}

Perlu diketahui bahwa, pembangunan infrastruktur transportasi merupakan bagian integral dari pembangunan nasional. Oleh karena itu, pembangunan infrastruktur diyakini sebagai motor pembangunan suatu kawasan, termasuk pembangunan industri. Berbagai upaya telah dilakukan pemerintah untuk menyediakan fasilitas dan layanan infrastruktur yang berkualitas, baik dalam bentuk pengaturan dengan kerangka regulasi maupun kerangka investasi melalui rehabilitasi dan peningkatan kapasitas fasilitas infrastruktur yang rusak, serta pembangunan baru. Kerangka kebijakan regulasi dan kerangka investasi diharapkan akan dapat meningkatkan ketersediaan fasilitas dan layanan infrastruktur (Basri, 2002).

Peningkatan pertumbuhan PDRB yang tinggi, sangat dipengaruhi oleh tersedianya infrastruktur transportasi pada suatu wilayah. Namun dari sisi penawaran (side supply), pemerintah terkendala dengan minimnya investasi (dana) untuk pemeliharaan maupun pembangunan baru untuk infrastruktur transportasi. Sedangkan di sisi lain, permintaan (side demand) terhadap infrastruktur transportasi sangat tinggi karena jumlah penduduk dalam Kota Ambon bertambah padat. Dengan demikian moda tranportasi bertambah pula untuk memenuhi permintaan pengguna jasa pengangkutan (bandingkan dengan Basri dan Munandar, 2009).

Walaupun ada upaya untuk mempercepat pembangunan infrastruktur dan/atau prasarana transportasi, memerlukan waktu yang tidak singkat dan dengan biaya yang besar. Oleh karena itu, menuntut adanya fokus serta keseriusan dalam mewujudkannya. Untuk menjamin bahwa pembangunan proyek tersebut dapat berjalan, mulai dari tahapan persiapan hingga operasi secara berkelanjutan diperlukan suatu kebijakan yang sinergis, solid, konsisten, dan tepat waktu dengan tetap menjaga kaidah-kaidah good governance (Susantono, 2013).

Upayauntukmencapai sasaran tersebut, maka diperlukan suatu perencanaan seperti rehabilitasi, pemeliharaan dan menyelesaikan pembangunan infrastruktur transportasi dengan mempertimbangkan efektivitas biaya dan kendala waktu serta faktor lainnya seperti, teknologi dan konsumen yang dilayani. Di samping itu, harus mempertimbangkan aspek peraturan dan perundang-undangan yang berlaku, seperti pelaksanaan otonomi daerah dan perimbangan keuangan antara pusat dan daerah. Melalui suatu perencanaan yang matang, maka pembangunan infrastruktur transportasi harus menjadi prioritas utama, terutama untuk menunjang pembangunan ekonomi secara makro maupun secara mikro yang lebih meningkat dan berkualitas.

Salah satu langkah yang telah ditempuh oleh pemerintah untuk meningkatkan kapasitas infrastruktur yang terbatas, terutama di tingkat daerah-daerah khususnya di kawasan Indonesia Bagian Timur, yaitu yang dikenal dengan konsep Master Plan Percepatan dan Perluasan Ekonomi Indonesia (MP3EI). Menurut Susantono (2013), pembangunan infrastruktur di Indonesia seolah mendapat kembali momentum melalui peluncuran MP3EI pada 27 Mei 2011. MP3EI dimaksudkan untuk membuat terobosan (breakthrough) dan bukan "business an usual" untuk mendorong terwujudnya pertumbuhan ekonomi yang tinggi, berimbang, berkeadilan, dan berkelanjutan. MP3EI kini menjadi panduan bagi proses perencanaan nasional yang menggabungkan konsep perencanaan kewilayahan dan sektoral.

Maksud dan tujuan pokok daripada MP3EI tidak lain adalah memperkokoh landasan perekonomian di daerah, melalui usaha untuk memacu/meningkatkan Produk Domestik Regional Bruto (PDRB). Dengan kata lain, keberhasilan pembangunan di daerah, salah satu tolok ukurnya adalah tingkat capaian PDRB-nya. Peningkatan PDRB yang signifikan tentu akan berdampak langsung pada Produk Domestik Bruto (PDB). Sehubungan dengan itu, maka laju PDRB sangat ditentukan juga oleh pembangunan infrastruktur transportasi yang memadai dan handal di daerah.

Infrastruktur merupakan roda penggerak pembangunan ekonomi, baik secara 
nasional maupun regional/daerah. Dari alokasi pembiayaan publik dan swasta, infrastruktur dipandang sebagai lokomotif pembangunan nasional dan daerah. Secara ekonomi makro ketersediaan dari jasa pelayanan infrastruktur memengaruhi marginal productivity of private capital, sedangkan dalam konteks ekonomi mikro, ketersediaan jasa pelayanan infrastruktur berpengaruh terhadap pengurangan biaya produksi. Disamping itu, infrastruktur juga berpengaruh penting bagi peningkatan kualitas hidup dan kesejahteraan manusia, seperti adanya peningkatan produktivitas tenaga kerja, akses terhadap lapangan kerja, dan peningkatan stabilisasi makro ekonomi, yaitu keberlanjutan fiskal, berkembangnya pasar kredit, dan pengaruhnya terhadap pasar tenaga kerja (Agenor, 2006).

Peran lainnya, adalah infrastruktur sebagai prasarana jaringan dasar dari keberadaan dari suatu kota atau wilayah merupakan faktor penting didalam keberlangsungan dan pertumbuhan kota atau wilayah (Grigg, 1998). Apabila dalam penyediaan dan pemeliharaan infrastruktur transportasi tidak dilakukan dengan baik, maka jaringan kota atau simpul kegiatan perkotaan didalam suatu wilayah menjadi terganggu, yang selanjutnya berdampak kepada degradasi sistem ekonomi dan sosial masyarakat (Kodoatie, 2003). Hal ini, menunjukkan bahwa keberadaan infrastruktur merupakan modal utama suatu wilayah untuk maju dan berkembang dalam usaha memacu dan merangsang perekonomian, yang signifikan, baik lingkup makro maupun mikro. Dengan kata lain, tanpa infrastruktur jalan, infrastruktur pelabuhan laut, dan infrastruktur bandar udara yang memadai, maka kemajuan pembangunan di semua aspek kehidupan manusia menjadi tidak berkembang (subsistence).

Sehubungan dengan itu, maka tidak dapat dipungkiri bahwa infrastruktur transportasi merupakan urat nadi bagi suatu wilayahyang sangat berperan untuk mendorong percepatan perkembangan suatu wilayah agar dapat menggerakkan perekonomian melalui siklus aliran barang maupun mobilitas manusia dari daerah yang satu ke daerah yang lain. Dengan adanya ketersediaan infrastruktur transportasi merupakan salah satu penyebab didalam memberikan daya eksternalitas yang sangat besar untuk peningkatan kegiatan perkonomian dalam suatu wilayah tertentu, secara bersimultan. Dalam artian, bahwa pembangunan infrastruktur transportasi mutlak telah tersedia, barulah pembangunan infrastruktur lainnya akan bisa berlangsung dan berkembang dengan baik termasuk pembangunan aspek kehidupan lainnya.

Pendapat di atas didukung oleh beberapa hasil penelitian, dimana cukup banyak studi yang mengungkapkan bahwa pembangunan infrastruktur sangat berperan dan mempengaruhi pertumbuhan ekonomi suatu negara atau wilayah (Aschauer, 1989; Munnel, 1990; dan Dikun, 2003 ). Bahkan studi yang dilaporkan oleh World Bank (1994), bahwa elastisitas Produk Domestik Bruto (PDB) terhadap infrastruktur transportasi di suatu negara adalah memberikan efek multipliernya sebesar $7 \%$ sampai dengan 44 $\%$, suatu variasi angka yang cukup signifikan. Pembangunan infrastruktur transportasi yang memadai diyakini sebagai faktor penentu dalam mendorong PDRB. Sejarah membuktikan bahwa tidak ada suatu kawasan atau negara di dunia yang tertinggal dibidang ekonomi karena pembangunan infrastrukturnya yang sangat memadai dan berkualitas. Justru dengan kondisi infrastruktur yang terbatas dan tidak berkualitas menunjukkan sebaliknya (Susantono, 2013), sehingga, tingkat pertumbuhan ekonomi regional/PDRB sangat dipengaruhi oleh pembangunan infrastruktur transportasi yang memadai dan makin meningkat dari tahun ke tahun.

Pertumbuhan PDRB tidak akan pernah berkembang dengan cepat dan maju, bila pembangunan infrastruktur transportasi, masih sangat terbatas. Tersedianya infrastruktur transportasi pada suatu wilayah, akan menyebabkan efek berantai terhadap pembangunan ekonomi lainnya. Efek berantai, yang dimaksudkan adalah efek yang ditimbulkan karena adanya kegiatan (pembangunan) sebelumnya 
sehingga mengakibatkan adanya rangkaian kegiatan lanjutan di bidang ekonomi secara terus-menerus. Singkatnya, efek berantai adalah efek yang diakibatkan oleh karena adanya penyebab utama, untuk selanjutnya menimbulkan efek lanjutan bagi peningktan perekonomian atau kehidupan sosial di suatu wilayah.

Akibat adanya efek berantai yang ditimbulkan dari ketersedian infrastruktur transportasi maka berbagai usaha atau industri, baik industri Usaha Kecil dan Menengah (UKM) maupun industri yang berskala besar, akan terus bertumbuh dan meningkat dengan cepat. Dengan adanya industri UKM dan industri berskala besar akan ada perluasan usaha sehingga dapat menciptakan lapangan kerja yang luas bagi para pengangguran sehingga ada pendapatan riilnya bagi para pekerja. Disamping itu, dengan tersedianya infrastruktur transportasi, maka pelayanan publik terhadap masyarakat oleh pemerintah semakin meningkat secara efektif, efisien, dan ekonomis. Semua ini tentunya akan berimplikasi pada tingkat pertumbuhan ekonomi regional Kota Ambon yang makin meningkat dari tahun ke tahun.

Infrastruktur transportasi yang ada di Kota Ambon, walau harus diakui bahwa pemerintah telah mencanangkan percepatan pembangunan infrastruktur transportasi agar tingkat pertumbuhan PDRB semakin meningkat.Salah satu langkah yang ditempuh adalah melibatkan sektor swasta untuk ikut serta dalam pembangunan infrastruktur rmelalui penanaman modal (investasi), baik pihak asing maupun nasional.Namun, bidang usaha di sektor infrastruktur transportasi di dalam negeri, khususnya di daerah belum ada minat (keuntungan yang menggiurkan) bagi pihak swasta. Hal ini dikarenakan, tingkat pengembalian modal butuh waktu yang cukup panjang sehingga pemerintah menjadi pemeran utama/tunggal untuk pembangunan atau pemeliharaan infrastruktur transportasi.

Kota Ambon, sebagai pusat kegiatan perekonomian (growth pole) di Provinsi Maluku, dan merupakan kota yang relatif besar dan padat permukiman penduduknya, seharusnya butuh ketersediaan infrastruktur transportasi yang sangat memadai dan berkualitas. Berarti, pembangunan infrastruktur transportasi yang meliputi jalan, pelabuhan dan bandar udara harus disinergikan dan proporsional serta ditingkatkan pembangunannya. Dengan demikian, ketiga jenis infrastruktur transportasi tersebut saling mendukung dan terkait akan dapat menciptakan eksternalitas ekonomi dalam rangka meningkatkan pertumbuhan ekonomi yang tinggi, baik secara kualitas maupun kuantitas.

Berhubungdenganadanyaketerbatasan Anggaran Pendapatan dan Belanja Negara (APBN) maupun Anggaran Pendapatan dan Belanja Daerah (APBD) Kota Ambon, maka akan berdampak pada kapasitas infrastruktur transportasi yang terbatas. Sedangkan untuk mengimbangi keterbatasan infrastruktur yang ada diperlukan anggaran yang minimal pula. Namun, yang terjadi adalah peningkatan permintaan tidak berbanding lurus dengan ketersediaan infrastruktur transportasi yang dibangun oleh Pemerintah Pusat dan Kota Ambon.

Kondisi demikian tentunya berdampak pada pembangunan dan/atau pemeliharaan infrastruktur transportasi yang terbatas sehingga memengaruhi Produk Domestik Regional Bruto (PDRB) Kota Ambon, yang belum tinggi pula. Apabila hal tersebut di atas dikaitkan dengan laju PDRB Kota Ambon sejak Tahun 2005 - 2015, berdasarkan PDRB perkapita atas dasar harga konstan tahun 2000, menunjukkan bahwa laju peningkatannya, hanya berkisar 5,42 persen per tahun.

Persoalannya, pembangunan dan pemeliharaan infrastruktur transportasi, sekarang belum memadai sehingga tingkat pertumbuhan PDRB pun belum meingkat sebagaimana yang diharapkan. Hal ini dapat dilihat dari kapasitas infrastruktur transportasi yang tidak memadai dan berkualitas. Jalan raya dari arah Desa Laha (bandar udara) sampai di dalam pusat Kota Ambon, masih terbatas karena sebagian besar belum ada pembatas jalan, trotoar, saluran air, dan lebar badan jalan yang tidak sama, padahal 
jalan tersebut merupakan salah satu koridor ekonomi di Kota Ambon. Disepanjang pada koridor tersebut adalah masih minimnya fasilitas penerangan sehingga menjadi salah satu penyebab seringnya terjadi kecelakaan di jalan.

Belum lagi, jika diperhadapkan dengan kapasitas infrastruktur jalan yang terbatas, mengakibatkan seringnya pengangkutan di jalan terkendala juga. Jalan raya dalam Kota Ambon sudah mengalami macet yang berkepanjangan pada titik-titik tertentu (jalan dari Gong Perdamaian masuk ke kompleks pasar, dan keluar dan dari arah terminal dan pasar sampai ke daerah Gong Perdamaian pula, dan dari pasar ke arah Benteng Merah dan Galunggung, demikian pun sebaliknya, jalan dari perempatan atau lingkaran ke arah pertigaan Batu Gantung hingga ke arah jalan utama ke Latuhalat dan ke arah tanjakan Kudamati. Kemacetan juga terjadi pada jalur keluar masuk terminal kearah Galunggung, Benteng Merah, dan Galala. Jalan-jalan dalam Kota Ambon tidak ada area khusus perparkiran, sehingga kenderaan diparkir pada sisi kiri dan kanan. Hal ini menyebabkan jalan-jalan dalam kota menjadi sempit. Permasalahan lainnya, adalah jalan-jalan ke arah pedesaan seperti Kayu Tiga dan Kayu Putih, Gunung Nona, Kusu-kusu, dan lainnya, ruas jalannya tidak lebar dan tidak berkualitas. Masalah yang lebih memprihatinkan adalah daya tampung (kapasitas) terminal sudah tidak memungkinkan lagi untuk tempat bongkar muat barang dan penumpang. Terminal, sekarang kapasitasnya dalam keadaan tertentu mengalami lumpuh total karena semua kenderaan dari pinggiran kota masuk ke terminal primer, ini terjadi karena tak ada terminal bayangan (sekunder) di dalam kota.

Infrastruktur pelabuhan laut pun mengalami hal yang tidak berbeda jauh dari kondisi kapasitas jalan raya. Kapasitas dermaga dan terminalnya relatif terbatas sehingga kenderaan angkut penumpang dan barang lambat karena area perputaran kenderaan di dalam sempit. Bongkar muat barang membutuhkan waktu yang cukup lama. Lapangan penumpukan barang (container) merupakan terminal pelabuhan untuk kenderaan bongkar muat. Selain itu, fasilitas bongkar muat dan panjang dermaga yang terbatas sehingga kapal sering menunggu giliran berlabuh untuk melakukan bongkar muat. Begitu pula dengan kenderaan bongkar muat sering antrian yang cukup lama, akhirnya pengangkutan barang yang tidak digudangkan dan langsung diangkut ke tempat tujuan menjadi terhambat.

Sedangkan untuk infrastruktur bandar udara, hambatannya adalah kapasitas bandara udaranya terbatas, yaitu panjang landasan pacu kurang dari 3.000 meter.Kapasitas bandar udara Pattimura, panjangnya hanya 2.500 meter, sehingga untuk penerbangan pesawat berukuran besar belum bisa untuk mendarat. Ukuran pesawat yang mendarat di bandar udara Pattimura hanya ukuran yang sedang, dan pesawat ukuran sedang yang mendarat hanyalah Buing 7357900 Air, dengan kapasitas penumpang maksimal 206 orang. Dengan kata lain, sebagai salah satu bandara udara bertaraf internasional, idealnya harus dapat didarati pesawat berukuran besar, dengan kapasitas penumpang lebih dari 206 orang. Persoalan utama lainnya adalah pesawat belum bisa mendarat pada malam hari karena keterbatasan fasilitas pendukung pada landasan pacu (runway). Oleh karena itu, pesawat yang akan landing (mendarat) dan take-off di Bandara Internasional PattimuraAmbon, hanya sampai pada jam 16.00 WIT. Akibat yang akan ditimbulkan dari permasalahan-permasalahan tersebut, adalah terhambatnya arus mobilitas/distribusi barang dan orang ke tempat tujuan menjadi terhambat. Semua kendala-kendala (kapasitas infrastruktur jalan, pelabuhan laut dan bandara udara tersebut, akan menciptakan efek/domino yang berantai. Efek yang paling berpengaruh adalah terutama biaya pengangkutan tinggi, berpengaruh pada tingkat harga yang tinggi dan akhirnya harga tersebut dibebankan pada konsumen. Efek lanjutannya adalah daya beli masyarakat relatif rendah. Daya beli dari masyarakat yang rendah maka aktivitas ekonomi akan jadi mandek, dan seterusnya. Bila demikian, akan berpengaruh 
negatif terhadap pertumbuhan ekonomi bagi Kota Ambon.

Berkaitan dengan itu, maka untuk kepentingan penelitian maka rumusan masalah yang dibangun meliputi: apakah pembangunan transportasi jalan, transportasi pelabuhan laut, dan transportasi udara berpengaruh signifikan terhadap Produk Domestik Regional Bruto di Kota Ambon? Sedangkan tujuan daripada penelitian tersebut adalah untuk menganalisis pembangunan transportasi jalan, transportasi pelabuhan laut, dan transportasi udara dapat memengaruhi Produk Dometik Regional Bruto di Kota Ambon ke depan. Karena itu, bila permasalah-permasalahan tersebut tidak dicari solusi pemecahannya secara serius maka akan berpengaruh negatif secara langsung pada kegiatan perekonomian (termasuk pelayanan publik), baik dalam lingkup mikro mapun makro.

Dengan demikian, peneliti tertarik untuk meneliti tentang apakah pembangunan infrastruktur transportasi dapat memengaruhi produk domestik regional bruto bagi Kota Ambon. Asumsi peneliti sementara bahwa, ketiga jenis infrastruktur transportasi tersebut merupakan faktor penentu dan paling berpengaruh dalam merangsang serta memacu laju produk domestik regional bruto yang signifikan. Sehubungan dengan itu, akhirnya peneliti merumuskan judul penelitiannya, sebagai berikut: "Analisis Pengaruh Pembangunan Infrastruktur Transportasi Terhadap Produk Domestik Regional Bruto Kota Ambon Provinsi Maluku".

\section{KAJIAN PUSTAKA}

Teori Dorongan Kuat (Big-Push Theory), yang menyatakan bahwa untuk dapat menanggulangi hambatan pembangunan ekonomi atau mempercepat adanya perubahan suatu pembangunan kearah kemajuan diperlukan suatu dorongan kuat melalui prioritas pembangunan dibidang ekonomi melalui pembangunan infrastruktur lebih dahulu, perkembangan yang lain akan menetes mengikutinya (trickle down effect), sehingga pada akhirnyan pertumbuhan ekonomi akan meningkat secara signifikan. Dengan kata lain, setiap penambahan modal/capital dalam pembangunan infrastruktur akan diikuti pula dengan peningkatan output.

Bila dikaitkan dengan ruang lingkup penelitian ini maka adalah tepat jika dikaitkan dengan teori Sutami yang mengatakan bahwa pembangunan infrastruktur yang handal akan memberikan kontribusi ekonomis dalam penggunaan potensi sumber daya alam yang ada di kawasan tersebut sehinggga dapat berfungsi sebagai penggerak dalam pengembangan wilayah. Sejalan dengan itu, maka ketersediaan infrastruktur transportasi tentu memberikan efek multiplier bagi proses kegiatan ekonomi, baik dari segi proses produksi, bertumbuhnya sektor industri karena adanya peningkatan output pada semua sektor ekonomi, penciptaan lapangan kerja, pendistribusian barang dan jasa termasuk mobilitas penduduk/orang menjadi lancar yang pada akhirnya dapat meningkatkan nilai tambah dalam wujud PDRB.

Sebelum melangka lebih jauh, maka ada baiknya perlu untuk memberikan batasan maupun lingkup daripada infrastruktur transportasi itu sendiri. Basri \& Munandar (2009) memilah menjadi tiga, yaitu: 1) infrastruktur keras fisik (physical hard infrastructure) adalah meliputi jalan raya, rel kereta api, bandara, dermaga dan pelabuhan, bendungan dan saluran irigasi, dan sebagainya; 2) infrastruktur keras nonfisik (nonphysical hard infrastructure), adalah infrastruktur yang berkaitan dengan fungsi dan utilitas umum, seperti listrik, jaringan telekomunikasi (telepon, internet), pengolahan air dan jaringan pipa penyaluran, pasokan energi mulai dari minyak bumi, biodiesel, dan gas berikut jaringan pipa distribusinya, dan lainnya; dan 3) infrastruktur lunak (soft infrastructure) atau biasa pula disebut kerangka institusional (kelembagaan) yang meliputi nilai (ternasuk etos kerja), norma (khususnya yang telah dikembangkan dan dikodifikasikan menjadi peraturan hukum dan perundangundangan), serta kualitas pelayanan umum yang disediakan oleh berbagai pihak terkait, khususnya pemerintah.

Banerjee, dkk, (2012), transportation 
infrastructure is often mentioned as a key to promoting growth and development. The argument relies on the simple logic that one first needs to have access to markets and ideas before one can benefit from them. Clearly (dalam Trimbath, 2011), define "transportation infrastructure" as the underlying structures that support the delivery of inputs to places of production, goods and services to customers, and customers to marketplaces. The structures are: transit, highways, airports, railways, waterways (ports), intermodal links.

Berdasarkan definisi diatas, maka yang dimaksud dengan infrastruktur transportasi adalah fasilitas-fasilitas dasar publik, seperti jalan, rel kereta api, pelabuhan laut, dan bandar udara yang disediakan oleh pemerintah dan/atau swasta dengan maksud memperlancar dan meningkatkan pelayanan atau pun perekonomian suatu wilayah/negara. Namun, infrastrutur yang dimaksudkan dalam penelitian ini adalah infrastruktur transportasi, yang meliputi: 1) infrastruktur jalan (ways infrastructure), 2) infrastruktur pelabuhan laut (seaport infrastructure), dan 3) infrastruktur bandar udara (airtport infrastructure).

Didalam suatu wilayah atau negara yang ingin perekonomiannya cepat tumbuh, berkembang dan maju, biasanya yang paling didahulukan adalah pembangunan infrastruktur, salah satunya adalah infrastruktur transportasi, terutama jalan, pelabuhan, bandar udara dan kemudian yang lainnya. Dengan demikian diharapkan kehandalan infrastruktur yang ada di daerah berpengaruh positif dan signifikan dalam meningkatkan pertumbuhan ekonomi (Calderon dalam Maryaningsih dkk, (2011).

Disadari atau tidak, jalan adalah suatu jalur di daratan yang sangat vital demi keberlangsungan kegiatan perekonomian dan mobilitas dari suatu penduduknya. Tanpa infrastruktur jalan di suatu wilayah maka dipastikan suatu wilayah atau negara akan tetap dalam keadaan subsisten bahkan terbelakang di semua aspek kehidupan dan penghidupan, oleh karena hubungan dengan dunia luar tidak memungkinkan (Susantono, 2013). Begitu vitalnya, infrastruktur transportasi jalan oleh karena merupakan sarana dan prasarana transportasi di daratan yang sekaligus melayani jasa daripada infrastruktur pelabuhan laut dan bandar udara. Oleh sebab itu, bongkar muat barang/penumpang yang ada disediakan oleh jasa pelabuhan laut dan bandara udara untuk didistribusikan ke daerah tujuan sangat ditentukan oleh ketersediaan jumlah angkutan yang beroperasi di Kota Ambon.

Hal lainnya, bahwa transportasi jalan merupakan syarat mutlak didalam pengangkutan barang dan orang dari suatu tempat ke tempat tujuan. Transportasi jalan yang tidak handal maka moda transportasi di daratan sebagai jasa pengangkutan tidak mungkin dapat berlangsung dengan baik. Aksesibilitas jalan yang merupakan simpulsimpul/jaringan jalan yang terdiri dari jalan nasional, jalan provinsi maupun jalan kota. Dengan demikian, moda transportasi yang ada sangat memudahkan mobilisasi barang/ jasa dan orang akan berjalan dengan lancar apabila didukung dengan transportasi jalan yang berkualitas. Argumen ini diperkuat oleh hasil penelitian yang menyatakan bahwa infrastruktur jalan memberikan pengaruh signifikan terhadap output perekonomian Yanuar (2006).

Pelabuhan sangat dibutuhkan untuk tempat berlabuhnya suatu kapal dalam berbagai ukuran dan jenisnya, karena itu pelabuhan laut sangat dipertimbangkan mengenai kapasitasnya sebagai tempat moda transportasi untuk melakukan bongkar muat barang dan turun naiknya penumpang. Secara umum, "pelabuhan adalah suatu daerah perairan yang terlindung terhadap badai, ombak, dan arus, sehingga kapal dapat mengadakan olah gerak, bersandar, membuang jangkar sedemikian rupa sehingga bongkar muat atas barang dan perpindahan penumpang dan barang dapat terlaksana dengan aman" (Jinca, 2011). Selanjutnya, keberadaan daripada transportasi laut sangat dibutuhkan didalam mendistribusikan barang melalui perdagangan baik tataran regional, nasional maupun antar negara. Disamping itu dapat menciptakan nilai ekonomis karena daya muatnya massal, murah dan efisien 
dalam pengangkutannya dari pelabuhan satu ke pelabuhan yang lainnya (Kramadibrata Dalam Putra \& Djalante, 2016).

Perlu diketahui bahwa untuk mewujudkan kelancaran bongkar muat kapal laut di pelabuhan dan efisien maka mutlak dibutuhkan prasarana dan sarana yang memadai dan perangkat yang sesuai dengan peradaban teknolgi perkapalan. Selain itu harus ada sinergitas antara prasarana pelabuhan dan peralatan bongkar muat barang/orang dengan sarana dan/atau moda pengangkutan yang memadai serta ditopang oleh adanya area/ depot yang memungkin proses pengangkutan oleh moda transportasi darat untuk diteruskan ke tempat tujuan yang lain (Jinca, 2011).

Bandar udara atau airport berarti a tract of leveled land where aircraft can take off and land, usually eguipped with hardsurfaced landing strips, a control tower, hangars, and accommodations for passengers and cargoes (Adisasmita, 2012). Karena itu, bandar udara dapat juga diartikan sebagai tempatnya suatu pesawat untuk mendarat (landing) dan lepas landas (take-off) setelah menurunkan barang atau manusia untuk diangkut oleh moda transportasi ke tempat tujuan akhir maupun menaikan manusia dan barang untuk selanjutnya diterbangkan ke tempat tujuan berikutnya secara cepat. Agar proses perpindahan pengangkutan dari pesawat ke moda transpotasi lainnya berjalan dengan efisien maka perlu didukung oleh sarana dan prasarana yang handal.

Transportasi udara mempunyai peranan yang sangat penting dalam menyediakan jasa pelayanan transportasi untuk pengangkutan manusia dan barang antara banda udara yang satu dengan bandara yang lain ataupun perpindaharaan pengangkutan dari bandara ke moda transportasi darat untuk didistribusikan ke tempat tujuan melalui transportasi jalan/ daratan. Dan yang terpenting dari hadirnya transportasi udara adalah memberikan pelayanan pengangkutan yang sangat cepat dibandingkan dengan moda transportasi yang lain dan dapat melayani daerah-daerah terpencil atau terisolasi secara geografis serta dapat merangsang siklus kegiatan perekonomian di suatu kawasan tertentu (Tusmar \& Mora, 2015).

Terkait dengan peran infrastruktur transportasi, salah satu pengaruhnya adalah pertumbuhan PDRB. Salah cara untuk mengetahui perkembangan ekonomi secara regional PDRB) berdasarkan harga berlaku (nilai barang dan jasa dalam setiap tahun) maupun harga konstan (nilai barang dan jasa atas dasar harga berlaku pada tahun tertentu sebagai tahun dasar) dalam rentang waktu tertentu, biasanya 1 tahun. Total PDRB setiap tahunnya diperoleh berdasarkan jumlah nilai tambah dari keseluruhan unit usaha yang diciptakan dalam suatu daerah tertentu. Untuk diketahui bahwa (widodo, 2006) "PDRB atas dasar harga berlaku dapat digunakan untuk melihat pergeseran struktur ekonomi, sedangkan penghitungan atas dasar harga konstan digunakan untuk mengetahui pertumbuhan ekonomi riil dari tahun ke tahun, dimana faktor perubahan harga telah dikeluarkan".

Ada 3 (tiga) pendekatan yang dipakai didalam menghitung PDRB, yaitu pendekatan produksi, pendapatan, dan pengeluaran. Namun, pendekatan yang digunakan dalam mengitung PDRB adalah pendekatan produksi. Dengan demikan, PDRB meliputi total nilai tambah barang dan jasa yang dihasilkan oleh berbagai unit produksi wilayah di suatu daerah berdasarkan kurun waktu tertentu, misalnya setahun. PDRB dengan pendekatan produksi meliputi: 1) pertanian, peternakan, kehutanan, dan perkebunan; 2) pertambangan dan galian; 3) industri dan pengolahan; 4) listrik, gas dan air bersih; 5) bangunan/konstruksi; 6) perdagangan, hotel dan restoran; 7) pengangkutan dan komunikasi; 8) keuangan, persewaan, dan jasa perusahaan; 9) jasa-jasa termasuk jasa pelayanan pemerintah.

Secara emperik, membuktikan bahwa peran infrastruktur transportasi sangat mempengaruhi pertumbuhan PDRB. Diantaranya, pertama: Pengaruh Infrastruktur pada Pertumbuhan konomi Wilayah Di Indonesia (R.B.Prasetyo \& Muhammad Firdaus, 2011). Dengan menggunakan Model 
Data Panel dan Fixed Effects, hasil penelitian menunjukkan bahwa pengaruh infrastruktur mempunyai nilai adjusted $R$-Squared sebesar 0,99 yang berarti model mampu menjelaskan variasi pertumbuhan ekonomi sebesar 99,51 persen. Sedangkan pada masing-masing variabel bebas berpengaruh signifikan. Dimana hasil elastisitasnya untuk tenaga kerja sebesar 0,44; modal elastisitanya 0,01 ; listrik elastisitasnya 0,33 ; jalan elastisitasnya 0,13 ; air bersih elastisitasnya 0,04 ; dan variabl dummy krisis dengan koefisien -0,14.

Kedua, Pengaruh sektor Transportasi Terhadap Produk Domestik Bruto Kabupaten Magetan (R. Intan dan E. Saputon, 2009). Berdasarkan analisis Shift share dan Regresi Berganda, bahwa peran sektor transportasi signifikan positif terhadap PDRB Kabupaten Magetan.

Ketiga, Pengaruh Transportasi Terhadap Pengembangan Ekonomi Regional Di Kabupaten Toba Samosir (P. Siregar, 2013). Hasil Regresi Berganda menunjukkan bahwa panjang jalan dan jumlah kendaraan tidak berpengaruh secara signifikan terhadap PDRB Kabupaten Toba Samosir. Panjang jalan berpengaruh terhadap kesempatan kerja. Sektor industri, pertanian dan jasa berperan dominan dalam dalam pertumbuhan PDRB.

Keempat, Dampak Pembangunan PrasaranaTransportasi TerhadapKesejahteraan Masyarakat (Purwantini dan Rivai, 2010) menemukan bahwa bangunan prasarana transportasi berdampak pada mobilitas pada masyarakat meningkat, waktu tempuh dan biaya transportasi ke beberapa fasilitas (perekonomian, pemerintahan, kesehatan, dan pendidikan) menurun. Kesempatan kerja semakin menurun semakin banyak dengan adanya adanya pembangunan jalan. Pemasaran hasil produksi pertanian maupun hasil industri semakin mudah. Pendapatan rata-rata rumah tangga meningkat secara absolut (153 persen) maupun riil (64 persen). Harga pangan (beras) relatif murah dibandingkan sebelum ada pembangunan jalan, terkait dengan proporsi konsumsi pangan campuran, yaitu jagung dan beras dari 25 persen menjadi rata-rata 50 persen.

\section{METODE PENELITIAN}

Metode penelitian yang digunakan dalam penelitian ini adalah metode kuantitatif, sedangkan alat analisis yang digunakan untuk menunjukkan adanya pengaruh variabel infrastruktur transportasi terhadap Produk Domestik Regional Bruto, adalah persamaan regresi berganda, secara matematis adalah sebagai berikut (Setiawan \& Kusrini, 2010):

$\mathrm{Y}=\beta_{0}+\beta_{1} \mathrm{X}_{1}+\beta_{2} \mathrm{X}_{2}+\ldots+\beta \rho \mathrm{X} \rho+\varepsilon$

Dimana:

Y = variabel respon (tak bebas/ dependen) yang bersifat acak (random)

$\mathrm{X}_{1}, \mathrm{X}_{2}, \ldots \mathrm{X} \rho=$ variabel penjelas (bebas / independen) yang bersifat tetap (fixed variable) $\mathrm{B}_{0}, \beta_{1}, \ldots \beta \rho=$ parameter (koefisien) regresi $\varepsilon=$ Variabel random error / galat /variabel pengganggu (disturbance term) variabel yang tidak menjelaskan (unexplanatory varable).

Berdasarkan model dasar di atas, dengan memecah infrastruktur transportasi menjadi tiga variabel independen yang diteliti, yaitu 1) infrastruktur transportasi jalan; 2) infrastruktur transportasi pelabuhan laut; dan 3) infrastruktur transportasi bandar udara, maka perlu menotasikan kembali sehingga terbentuklah suatu model regresi berganda dengan menggunakan Logaritma Natural (Ln), yaitu:

$\mathrm{LnY}=\beta_{0}+\beta_{1} \operatorname{LnIJX}_{1}+\beta_{2}$ LnIPLX $_{2}+$ $\beta_{3} \operatorname{LnIBUX}_{3}+\varepsilon$

Dimana :

LnY $=$ Produk Domestik Regional Bruto Kota Ambon

LnIJX $_{1} \quad=$ Infrastruktur Jalan

LnIPLX $_{2}=$ Infrastruktur Pelabuhan

Laut

LnIPUX $_{3}=$ Infrastruktur Bandara Udara

$\beta_{0}=$ Intercept $/$ Parameter

$\beta_{1 \mathrm{~S}} / \mathrm{d} \beta_{3} \quad=$ Koefisien Regresi

$\varepsilon=$ Error Term

Alat analisis regresi berganda tersebut di atas bertujuan untuk mengestimasi dan/ atau menganalisis pengaruh variabel-variabel independen terhadap variabel dependen. Dengan kata lain, alat analisis regresi berganda yang telah ditransformasi ke logaritma natural adalah bertujuan untuk menguji tiga hipotesis 
yang ada dalam penelitian ini. Jenis data yang digunakan dalam penelitian ini adalah data Time Series. Data yang digunakan disini adalah meliputi data jumlah angkutan jalan, data jumlah kunjungan kapal, dan data frekuensi kunjungan (penerbangan) pesawat.

Berkaitan dengan teknik analisis yang digunakan, maka hipotesis yang dibangun dalam penelitian tersebut, adalah:

a. Diduga bahwa, pembangunan infrastruktur transportasi jalan berpengaruh signifikan terhadap Produk Domestik Regional Bruto (PDRB).

b. Diduga bahwa, pembangunan infrastruktur transportasi pelabuhan laut berpengaruh signifikan terhadapProduk Domestik Regional Bruto (PDRB).

c. Diduga bahwa, pembangunan infrastruktur transportasi bandar udara berpengaruh signifikan terhadapProduk Domestik Regional Bruto (PDRB).

\section{HASIL DAN PEMBAHASAN}

Berdasarkan hasil regresi berganda dari pengaruh variabel infrastruktur jalan terhadap PDRB Kota Ambon, menunjukkan bahwa hasil uji serentak/simultan (uji F) diperoleh Fhitung sebesar 54.294 dengan tingkat signifikansi 0,000 . Berhubung nilai probabilitasnya adalah 0,000 berada jauh di bawah $\alpha=0,05$ sehingga model regresi tersebut dapat digunakan untuk memprediksi adanya peningkatan PDRB. Artinya, variabel jumlah angkutan jalan, kunjungan kapal, dan frekuensi penerbangan pesawat secara simultan berpengaruh secara signifikan terhadap PDRB Kota Ambon. Sedangkan uji parsial (Uji t) adalah untuk menguji pengaruh variabel infrastruktur transportasi yang terdiri dari infrastruktur jalan, infrastruktur pelabuhan laut, dan infrastruktur bandar udara terhadap PDRB Kota Ambon. Syarat untuk mengambil keputusan menerima atau menolak suatu hipotesis diperlukan pengujian hubungan kausal dengan metode analisis regresi linear berganda, yaitu dengan cara membandingkan nilai probabilitas dengan taraf signifikan sebesar $\alpha=0,05$ (5 persen), dimana: 1) Jika probabilitas > 0,05 maka Ho diterima; dan 2)
Jika probabilitas $<0,05$ maka $\mathrm{H}_{0}$ ditolak.

Berdasarkan hasil pada tabel coefficients pada kolom significance, dengan cara membandingkan nilai probabilitas sebesar $0,010<0,05$ maka $\mathrm{H}_{0}$ ditolak. Dengan demikian, dapat dikatakan bahwa variabel infrastruktur jalan secara parsial berpengaruh secara signifikan terhadap PDRB Kota Ambon. Temuan ini sejalan dengan teori, bahwa bila terjadi peningkatan penggunaan modal dalam bentuk investasi infrastruktur jalan tentu akan meransang pertumbuhan output. Dengan kata lain, peran infrastruktur jalan melalui sektor pengangkutan memberikan andil yang besar didalam mendistribusikan barang dan orang secara efektif dan efisien. Karena itu, kapasitas infrastruktur jalan yang memadai dan berkualitas akan memperlancar arus migrasi moda transportasi (angkutan jalan) untuk mengangkut barang dan orang ke tempat tujuan secara cepat, aman dan efisien.

Apabila dikaitkan dengan panjang jalan dalam Kota Ambon adalah 352.704 meter, dimana dari sisi jenis permukaan jalan, sekitar 8.340 meter yang belum diaspal (4.290 meter adalah berkerikil; 4.050 meter adalah masih berupa tanah), sedangkan dari aspek kondisi jalan, jalan kota yang mengalami kerusakan ringan adalah sepanjang 45.820 meter, dan rusak berat adalah sepanjang 7,500 meter. Hasil tersebut menunjukkan bahwa infrastruktur jalan relatif baik dan berkualitas, sehingga dapat memperlancar kegiatan pengangkutan barang/orang ke tempat tujuan serta dapat meningkatkan PDRB bagi Kota Ambon.

Syarat untuk menguji pengaruh variabel pelabuhan laut terhadap PDRB Kota Ambon adalah dilakukan dengan cara membandingkan nilai probabilitas 0,309 > 0,05 . Berdasarkan hasil perbandingan tersebut, dapat disimpulkan bahwa $\mathrm{H}_{0}$ diterima. Artinya, variabel infrastruktur pelabuhan laut secara parsial belum berpengaruh secara signifikan terhadap PDRB Kota Ambon. Hal ini kemungkinan dapat terjadi karena: 1) data yang digunakan tidak sesuai dengan konteks persamaan tersebut; 2) kontribusi pendapatan dari retribusi di pelabuhan laut, ternyata kecil 
sehingga pengaruhnya terhadap pertumbuhan PDRB belum signifikan; 3) pendapatan dari sektor pajak/bea cukai merupakan kewenangan dari Pemerintah Provinsi dan Pusat.

Berdasarkan hasil pengamatan dan wawancara yang dilakukan dengan salah satu responden, mengatakan bahwa dari kapasitas infrastruktur pelabuhan laut yang ada masih terbatas, terutama lapangan penumpukan/depo dipelabuhan belum ada. Depo yang ada sekarang adalah sebenarnya untuk terminal kendaraan/peralatan bongkar muat di pelabuhan dan angkutan kendaraan darat. Lapangan penumpukan container (Depo) menjadi over kapasitas sehingga berpengaruh pada bongkar/muat di pelabuhan menjadi terhambat sehingga berpengaruh terhadap frekuensi kunjungan kapal. Hambatan-hambatan inilah menjadi penyebab infrastruktur transportasi pelabuhan laut belum meningkatkan PDRB bagi Kota Ambon.

Syarat untuk menguji pengaruh variabel infrastruktur transportasi bandara udara terhadap PDRB Kota Ambon adalah dilakukan dengan cara membandingkan nilai probabilitas $0,093>0,05$. Perbandingan nilai tersebut, dapat disimpulkan bahwa $\mathrm{H}_{0}$ diterima. Hal ini berarti, variabel infrastruktur transportasi bandara udara secara parsial belum berpengaruh secara signifikan terhadap PDRB Kota Ambon. Hal ini dapat terjadi karena kontribusi pendapatan dari retribusi, ternyata sangat kecil. Sedangkan pendapatan dari sektor pajak dan bea cukai merupakan kewenangan dari Pemerintah Provinsi Maluku, dan Pemerintah Pusat. Penyebab lainnya adalah fasilitas pendukung terutama approach lights di sekitar kawasan area landasan pacu (runway) dan fasilitas glide path masih terbatas sehingga pesawat tidak bisa mendarat di malam hari. Disamping itu, panjang landasan pacu (runway) masih terbatas (hanya $2.500 \mathrm{~m}$ ) sehingga pesawat yang berkapasitas daya muat diatas 206 penumpang tidak bisa mendarat dan hal ini berdampak pada belum mendongkrak PDRB bagi Kota Ambon.

Berdasarkan hasil penelitian dari ketiga variabel independen ditemukan bahwa: Pertama, secara simultan infrastruktur transportasi yang paling tinggi pengaruhnya terhadap PDRB Kota Ambon, adalah infrastruktur jalan. Hal ini disebabkan karena infrastruktur jalan melalui sektor pengangkutan di jalan raya sangat berperan untuk mendistribusikan barang/orang secara efektif dan efisien. Argumen ini diperkuat dengan hasil koefisien regresinya adalah 0,437. Artinya, setiap penambahan 1 unit angkutan jalan di Kota Ambon akan menyebabkan peningkatan terhadap PDRB sebesar Rp 437.000 juta. Kemudian disusul oleh infrastruktur pelabuhan laut dengan koefisien regresinya sebesar 0,146 . Hal ini berarti setiap kunjungan kunjungan kapal di pelabuhan Kota Ambon, akan menyebabkan peningkatan PDRB Kota Ambon sebesar Rp 146.000 juta. Sedangkan yang paling rendah pengaruhnya terhadap pertumbuhan ekonomi adalah infrastruktur bandara udara, karena koefisien regresinya hanya sebesar 0,036. Artinya setiap penambahan 1 penerbangan pesawat akan meningkatkan PDRB Kota Ambon sebesar Rp 36.000 juta.

Kedua, secara parsial infrastruktur transportasi pelabuhan laut dan transportasi udara belum mempengaruhi peningkatan PDRB Kota Ambon. Pada hal secara teoritik mengatakan ketersediaan transportasi yang memadai tentu akan berperan dalam meningkatkan PDRB terutama dari sektor jasa pengangkutan, namun tidak demikian. Hal ini dapat disebabkan karena barang dan jasa yang di angkut oleh transportasi laut lebih banyak didatangkan dari luar Kota Ambon (Kepulauan Maluku), sedangkan jasa transportasi Bandar udara lebih cenderung mengangkut orangorang dibandingkan dengan komoditi/barang. Dengan kata lain, masyarakat Kota Ambon adalah masyarakat yang relatif cenderung konsumtif, bukan masyarakat yang cenderung produktif.

\section{SIMPULAN DAN SARAN}

Berdasarkan hasil analisis data mengenai analisis pengaruh pembangunan pembangunan infrastruktur transportasi terhadap Produk Domestik Regional Bruto 
(PDRB) Kota Ambon diperoleh kesimpulan, sebagai berikut:

a. Pengaruh pembangunan infrastruktur jalan secara parsial berpengaruh secara signifikan terhadap PDRB Kota Ambon. Hal ini diperkuat dengan nilai probabilitas $0,010<0,05$. Dengan demikian, dapat disimpulkan bahwa $\mathrm{H} 0$ ditolak. Hal ini dikarenakan, kapasitas infrastruktur jalan yang ada dalam Kota Ambon memungkinkan mobilitas pengangkutan menjadi lancar, sehingga kegiatan ekonomi masyarakat makin bertumbuh dan meningkat dari waktu ke waktu.

b. Infrastruktur pelabuhan laut secara parsial belum berpengaruh secara signifikan terhadap pertumbuhan ekonomi Kota Ambon. Hasil tersebut didukung oleh nilai probabilitas 0,309 > 0,05 yang berarti H0 diterima. Hal ini terjadi karena kontribusi retribusi dari infrastruktur pelabuhan laut, ternyata kecil sehingga belum berpengaruh terhadap PDRB Kota Ambon. Penyebab lainnya adalah masih terbatasnya prasarana dan sarana seperti depo dan moda bongkar muat, akibatnya waktu menunggu untuk berlabuh dan bongkar muat kapal menjadi lama sehingga frekuensi kedatangan kapal tidak maksimal/meningkat.

c. Pengaruh infrastruktur bandara udara secara parsial belum berpengaruh terhadap PDRB Kota Ambon,karena nilai probabilitas $0,093>0,05$. Berhubung nilai probabilitas jauh lebih besar daripada $\alpha=0,05$ maka $\mathrm{H} 0$ diterima. Hal ini terjadi karena 1) pendapatan dari retribusi pelayanan bandar udara, ternyata kontribusinya kecil terhadap pembentukan PDRB Kota Ambon; 2) fasilitas pendukung (approach light, glide path dan panjang landasan belum 3.000 meter) infrastruktur bandar udara masih terbatas sehingga sebelumnya pesawat belum bisa mendarat di malam hari dan ukuran pesawat yang besar belum bisa mendarat sehingga berpengaruh terhadap frekuensi penerbangan pesawat.

Berdasarkan hasil kesimpulan di atas, maka peneliti memberikan saran-saran sebagai berikut:

a. Pembangunan infrastruktur jalan masih sangat berpeluang untuk dapat meningkatkan Produk Domestik Regional Bruto (PDRB) Kota Ambon, maka Pemerintah (Pusat, Provinsi dan Kota) didalam kebijakan pembangunan, kapasitas infrastruktur jalan perlu ditingkatkan secara proporsional, dan bersinergi dengan cara perlu merelokasi Pedagang Kaki Lima (PKL) ke tempat tertentu. Demikian pula, terminal maupun area parkir disediakan agar mobilisasi kendaraan dan arus angkutan barang menjadi lebih cepat serta aman.

b. Agar kapasitas infrastruktur pelabuhan laut berpengaruh secara signifikan terhadap PDRB Kota Ambon, maka pemerintah dengan pihak terkait supaya kapasitas depo dan fasilitas bongkar muat barang diprioritaskan untuk pembangunan kedepan sehingga bongkar muat dan arus distribusi barang ke tempat tujuan menjadi lancar.

c. Agar infrastruktur bandar udara berpengaruh secara signifikan terhadap PDRB Kota Ambon, maka Pemerintah dan instansi terkait selaku eksekutor dilapangan perlu menambah panjang landasan pacu supaya pesawat berukuran besar dapat mendarat dan fasilitas approach lights dan glide path harus ditingkatkan kemampuannya sehinnga pesawat dapat mendarat di malam hari.

\section{IMPLIKASI}

Implikasi kebijakan yang diharapkan setelah mempertimbangkan kesimpulan adalah:

a. Untuk infrastruktur pelabuhan laut dan udara sangat dibutuhkan campur tangan dari Pemerintah untuk memaksimalkan prasarana dan sarana/peralatan bongkar muat yang mengikuti perkembangan teknologi pelabuhan laut sehingga jumlah kunjungan kapal laut untuk berlabuh tidak bergantung sistem antrian.

b. Bagi infrastruktur bandar udara agar kapasitas prasarana dan sarana/peralatan harus dioptimalkan agar frekuensi penerbangan pesawat meningkat terutama di malam hari, baik pada saat mendarat maupun tinggal landas.

c. Bila kedua infrastruktur transportasi tersebut menjadi perhatian serius maka akan 
meningkatkan nilai tambah (PDRB) bagi Kota Ambon.

d. Selain itu, agar kontribusi infrastruktur transportasi bandar udara dan pelabuhan laut dapat meningkatkan PDRB Kota Ambon maka perlu ada kebijakan dalam pembagian hasil pendapat berupa pajak dan/atau bea cukai kepada pemerintah Kota Ambon.

e. Adapun kontribusi teoritis dari penelitian tersebut adalah berfungsi sebagai pengembangan ilmu pembangunan wilayah dimasa akan dating.

\section{DAFTAR PUSTAKA}

Adisasmita, R., (2005). Pembangunan Ekonomi Perkotaan, Penerbit Graha Ilmu, Yogyakarta.

Adisasmita, S. A,( 2012). Penerbangan dan Bandar Udara, Penerbit Graha Ilmu, Yogyakarta.

Agenor, P.R., (2006). A Theory of Infrastructure-led Development, Discussion paper series, Number 038, Center for Growth and Business Cycle Research, Economic, Studies, University of Manchester, Manchester.

Banerjee, dkk, (2012). On The Road: Access To Transportation Infrastructure And Economic Growth In China, NBER Working Paper No. 17897. P 1 - 50.

Basri, F., (2002). Perekonomian Indonesia: Tantangan dan Harapan Bagi Kebangkitan Indonesia, Penerbit Erlangga, Jakarta.

Basri dan Munandar, (2009). Lanskap Ekonomi Indonesia, Kajian dan Renungan Terhadap Masalah-masalah Struktural, Transformasi Baru, dan Prospek Perekonomian Indonesia, Penerbit Kencana, Jakarta.

Dikun, S., (2003). Infrastruktur Indonesia: Sebelum, Selama, dan Pasca Krisis; Kementerian Negara
PPN/BAPPENAS, Jakarta.

Ghozali, I., (2005). Aplikasi Analisis Multivaria Managementte dengan Program SPSS, Penerbit Universitas Diponegoro, Semarang.

Jinca, M. Y., (2011). Transportasi Laut Indonesia: Analisis Sistem \& Studi Kasus, Penerbit Brilian Internasional, Surabaya.

Kodoatie, R.J., (2003). Pengantar manajemen Infrastruktur, Penerbit Pustaka Pelajar, Yogyakarta.

Orr, R., (2008). Transportation Finance In California, Working Papers, Collaboratory for Research On Global Porjects, California.

Maryaningsih, N., dkk., (2014). Pengaruh Infrastruktur Terhadap Pertumbuhan Ekonomi Indonesia. Buletin Ekonomi Moneter dan Perbankan. Volume 17, No 1, Juli 2014.

Prasetyo, Firdaus, (2009). Jurnal Ekonomi dan Kebijakan Pembangunan: Pengaruh Infrastruktur Pada Pertumbuhan Ekonomi Wilayah Di Indonesia, IPB, Bandung.

Putra, Adris A \& Djalanti S., (2016). Pengembangan Infrastruktur Pelabuhan Dalam Mendukung Pembangunan Berkelanjutan. Jurnal Ilmiah Media Engineering. Vol. 6 No. 1 Januari 2016.

Setiawan, Kusrini (2010). Ekonometrika: Analisis Regresi, Multikloneritas, Heteroskedastisitas, Otokorelasi, Sistem Persamaan Simultan, Model dinamis, Penerbit CV. Andi Offset, Yogyakarta.

Susantono, B., (2013). Transportasi \& Investasi: Tantangan dan Perspektif Multidimensi, Penerbit PT. Kompas 
Media Nusantara, Jakarta.

Trimbath, S., (2011). Trasportation Infrastructure: Paving The Way, US Chamber of Commerce Technical Report, US Chamber.

Tusmar, T \& Mora, M., (2015). Perkembangan Perekonomian Wilayah dan Kargo Udara: Korelasi atau Kausalitas? Jurnal Perhubungan Udara: Warta Ardhia, Vol. 41 No. 1, Hal. 39 - 48. Jakarta.
World Bank, (1994). World Development Report: Infrastructure for Development, Oxford University Press, New York.

Yanuar, R., (2006). Kaitan Pembangunan Infrastruktur dan Pertumbuhan Output serta Dampaknya Terhadap Kesenjangan Di Indonesia. Tesis Magister Sains. Program Pascasarjana IPB, Bogor. 